\title{
Expression of the potential biomarker heat shock protein 70 and its regulator, the metazoan DnaJ homolog, by temperature stress in the sponge Geodia cydonium
}

\author{
Claudia Koziol ${ }^{1}$, Renato Batel ${ }^{2}$, Emel Arinc ${ }^{3}$, Heinz C. Schröder ${ }^{1}$, Werner E. G. Müller ${ }^{1, *}$ \\ 'Institut für Physiologische Chemie, Universität, Duesbergweg 6, D-55099 Mainz, Germany \\ ${ }^{2}$ Center for Marine Research, 'Rudjer Boskovic' Institute, HR-52210 Rovinj, Croatia \\ ${ }^{3}$ Department of Biology, Middle East Technical University, Inönü Bulvari, TR-06531 Ankara, Turkey
}

\begin{abstract}
Because sponges (Porifera) are generally the dominant group of multicellular animals found in the marine benthos they are key animals for the testing of biomarkers in this biotope. Previously, it was shown that the heat shock protein hsp70 from the marne sponge Geodia cydonium is a useful biomarker for following biological responses to selected physical and chemical stressors. One protein which is critical for hsp70 function in other organisms is the DnaJ-like protein. In this study we therefore isolated and characterized a cDNA encoding the DnaJ-like protein from G. cydonium designated GCDNAJ. GCDNAJ is 1476 base pairs (bp) long with a 1236 bp open reading frame encoding a protein of 45542 daltons. Northern blot analysis revealed a transcript size of 1.5 kilobase (kb). The deduced amino acid (aa) sequence of GCDNAJ contains motifs characteristic of most prokaryotic and eukaryotic DnaJ family members. In response to a $7^{\circ} \mathrm{C}$ temperature increase, expression of the transcripts encoding hsp70 and DnaJ-like protein increased as much as 18-fold and 3-fold, respectively, within a $8 \mathrm{~h}$ period. From these data we conclude that the levels of both hsp 70 and DnaJ-like protein are likely to be important to the adaptation to temperature increases in G. cydonium.
\end{abstract}

KEY WORDS: Geodia cydonium - DnaJ-like protein - Heat shock protein - Sponge hsp70

\section{INTRODUCTION}

The simplest and the most ancient metazoan phylum, the sponges (Porifera), which branched off first from the common ancestor of all Metazoa (Müller 1995) are also the most numerous multicellular animals found in the marine hard-substrate benthos, both with respect to the number of species and in biomass (Sarà \& Vacelet 1973). All sponges live in the aquatic environment; adult specimens are sessile filter-feeders ingesting particles of sizes between 5 and $50 \mu \mathrm{m}$ through the cells of the mesohyl and the pinacoderm, and microparticles $(0.3$ to $1 \mu \mathrm{m})$ via the cells of the choanocyte chambers. A specimen of $1 \mathrm{~kg}$, e.g. a small Geodia cydonium, filters $\sim 24000$ l every day (Vogel 1977).

\footnotetext{
- Addressee for correspondence

E-mail: wmueller@goofy.zdv.uni-mainz.de
}

Sponges must utilize strategies - as also present in higher metazoan phyla - to react to environmental hazards and to prevent stress-induced damage by repairing macromolecules, cells and/or tissue-like assemblies. Consequently, sponges appear to be suitable systems to assess the impact of pollution (Müller 1994, Müller \& Müller 1997, Scheffer et al. 1997). Sponges probably react to chemical and physical stress with a series of physiological responses; this makes it difficult to select a biomarker for biological monitoring. A biomarker is defined as 'a xenobiotically-induced variation in cellular or biochemical components or processes, structures, or functions that is measurable in a biological system or sample' (NRC 1989). Challenging Eucarya by environmental stress results in the induction of expression of several genes, most prominently acute phase genes and heat shock genes. The acute phase response is complex, usually mediated 
by signal molecules which cause cell-type specific responses. In contrast to the heat shock response, the acute phase response is triggered by (1) a lower level of stimulus and (2) less severe challenges (Buchman et al. 1993).

Heat shock response is a fundamental function of all living organisms, allowing the maintenance of homeostasis even under the influence of environmental stressors occurring at strongly varying levels (Morimoto et al. 1994). In response to hyperthermia or protein denaturing agents the organisms respond with a strong and transient expression of a number of genes encoding heat shock proteins (hsp); their main members are hsp90, hsp70, hsp58-60 and hsp20-30, and as a fifth hsp, ubiquitin (Schlesinger et al. 1982).

Previously we could show by metabolic labeling followed by electrophoresis (Müller et al. 1995) and with cDNA probes (Koziol et al. 1996) that hsp70 is a biomarker in both freshwater sponges (Ephydatia fluviatilis) and marine sponges (Geodia cydonium). Its determination requires only minute tissue samples and does not destroy the organism. Hence, this biomarker can be grouped with the nondestructive biomarkers (Fossi 1994). The usefulness of hsp70 as a biomarker is also supported by the finding that it is induced in sponges not only after temperature stress (Koziol et al. 1996, Bachinski et al. 1997), but also in response to $\mathrm{pH}$ changes (Koziol et al. 1996) and exposure to xenobiotics (Müller et al, 1995).

The hsp70s function as molecular chaperones that assist folding of polypeptides, under both normal and temperature stress conditions (Gething \& Sambrook 1992). Experimental evidence was presented showing that mammalian hsp70 forms a complex with a novel $40 \mathrm{kDa}$ heat-shock protein, hsp40 (Ohtsuka et al. 1990), indicating a cooperative function (Yamane et al 1995). cDNA cloning experiments revealed that the mammalian hsp40 is a homologue of bacterial DnaJ hsp (Ohtsuka 1993); it is termed DnaJ-like protein. In Bacteria the interaction of DnaK with DnaJ results in a stimulation of ATPase activity displayed by DnaK (Liberek et al. 1991, Boguski \& McCormick 1993, Georgopoulos et al. 1994). In Eucarya a similar stimulatory effect has been suggested for the DnaJ-like protein on the ATPase activity of hsp 70 (Cheetham et al. 1994). Most chaperones which are induced and expressed under temperature stress have a constitutively expressed counterpart, present also under nonstressed conditions (Subjeck \& Shyy 1986). Among them is the glucose-regulated protein of the $78 \mathrm{kDa}$ class (GRP78) which resides in the endoplasmic reticulum; in addition GRP78 was found to bind to immunoglobulin heavy-chains in pre-B cells (Munro \& Pelham 1986, Haas \& Meo 1988). In sponges a member of the hsp70s from Geodia cydonium (Koziol et al.
1996) and one belonging to the GRP78s from Suberites domuncula (Koziol et al. unpubl.) have been cloned.

To further establish hsp70 as a suitable biomarker requires the elucidation of those molecules which are - besides hsp70-involved in the chaperone machinery. This is firstly the DnaJ-like protein, which is associated with hsp70 in the cytoplasm; this complex is translocated in the nucleus during heat shock (Yamane et al. 1995). The second molecule is the GrpE homo$\log$ which associates with mitochondrial hsp70 during mitochondrial protein uptake (Bollinger et al. 1994). Genes coding for DnaJ-like proteins from Eucarya and their corresponding genes from Bacteria-Archaea are known to respond to heat stress by increased expression; e.g. in Eucarya, in animals (human; Yamane et al. 1995) as well as in plants (the cucumber Cucumis sativus; Preisig-Müller \& Kindl 1993), and in Bacteria (Lactococcus lactis; van Asseldonk et al. 1993) as well as in Archaea (Methanosarcina mazei; Macario et al. 1993). Therefore, we isolated the DnaJ-like protein from the sponge Geodia cydonium and analyzed its expression during heat stress.

\section{MATERIALS AND METHODS}

Materials. Restriction endonucleases and other enzymes for recombinant DNA techniques and vectors were obtained from Stratagene (La Jolla, CA, USA), Qiagen (Hilden, Germany), Boehringer Mannheim (Mannheim, Germany), GibcoBRL (Grand Island, NY, USA), Amersham (Buckinghamshire, UK), USB (Cleveland, OH, USA), Dupont (Bad Homburg, Germany) and Promega (Madison, WI, USA). DIG (digoxigenin) DNA labeling kit, DIG-11-dUTP, anti-DIG APFab fragments and CDP [disodium 2-chloro-5-(4-methoxyspiro[1,2dioxetane-3,2' -(5'-chloro)-tricyclo[3.3.1.1-3,7]decan]4-yl)phenyl phosphate] came from Boehringer Mannheim.

Sponge and incubation conditions. Live specimens of Geodia cydonium (Porifera, Demospongiae, Tetractinomorpha, Astrophorida, Geodiidae) were collected near Rovinj (Croatia). Soon after collection from a depth of $25 \mathrm{~m}$ at $16^{\circ} \mathrm{C}$ (ambient temperature) they were used for the experiments.

Incubation was performed in filtered, oxygenated seawater. The samples were treated as follows: animals (weight 200 to $500 \mathrm{~g}$ ) were cut into cubes (of $0.5 \mathrm{~cm}$ sides) which either remained untreated at $16^{\circ} \mathrm{C}$, 'controls', or, in parallel, were treated at an elevated temperature of $23^{\circ} \mathrm{C}$ for the entire incubation period, 'treated samples'.

Polymerase chain reaction-cloning of GCDNAJ from Geodia cydonium. The N-terminus of the cDNA encoding sponge DnaJ-like protein was cloned by poly- 
merase chain reaction (PCR) from a G. cydonium cDNA library (Pfeifer et al. 1993) in lambda ZAPII, using the degenerate reverse primer 5'-RTCIGGRTGRTAHAIICTIGC- $3^{\prime}$ (where $\mathrm{I}=$ inosine; $\mathrm{H}=\mathrm{C} / \mathrm{T}$ and $\mathrm{R}$ $=\mathrm{A} / \mathrm{G}$ ) in conjunction with the ZAPII $5^{\prime}$-end vectorspecific primer T3. The PCR reaction mixtures of $50 \mu \mathrm{l}$ included $10 \mathrm{pmol}$ of the degenerate primer and $5 \mathrm{pmol}$ of the primer T3 (Stratagene), $200 \mu \mathrm{M}$ of each nucleotide, $1 \mu \mathrm{l}$ of the cDNA library |approximately $10^{9}$ plaque-forming units (pfu)], buffer and 2.5 units of Taq DNA polymerase (Boehringer Mannheim). PCR amplifications were run on a GeneAmp 9600 thermal cycler (Perkin Elmer) with the following cycling parameters: an initial denaturation of $3 \mathrm{~min}$ at $95^{\circ} \mathrm{C}$, then 35 cycles of $95^{\circ} \mathrm{C}$ for $45 \mathrm{~s}, 56^{\circ} \mathrm{C}$ for $1 \mathrm{~min}, 74^{\circ} \mathrm{C}$ for $90 \mathrm{~s}$, and a final extension step at $74^{\circ} \mathrm{C}$ for $10 \mathrm{~min}$. After electrophoresis 1 band of 1.0 kilobase $(\mathrm{kb})$ was observed in the ethidium bromide-stained gel. Amplification products were purified through a QIAquick Spin column (Qiagen), cloned in bulk into pGEM-T (Promega) and 4 independent clones were sequenced (Sequenase version 2.0, USB). The sponge cDNA coding for DnaJ homologue was designated GCDNAJ. A flanking forward primer to the 5' of the GCDNAJ gene was designed to complete the C-terminus of GCDNAJ from the cDNA library, in conjunction with the ZA.PII 3 '-end vector-specific primer T7. PCR reactions were performed as described above except that 5 pmol each of the internal forward primers and T7 (Stratagene) primers were used, and the cycling parameters were: 3 min at $95^{\circ} \mathrm{C}$, then 35 cycles of $95^{\circ} \mathrm{C}$ for $45 \mathrm{~s}, 62^{\circ} \mathrm{C}$ for $45 \mathrm{~s}, 74^{\circ} \mathrm{C}$ for $90 \mathrm{~s}$, and 1 extension step $\left(74^{\circ} \mathrm{C} ; 10 \mathrm{~min}\right)$. The amplification product was cloned and sequenced.

DNA sequencing was performed with an automatic DNA sequenator (Li-Cor 4000 S).

Sequence comparisons. Sequences were analyzed using computer programs from PC/GENE (1995) (BLITZ@ebi.ac.uk and FASTA@ebi.ac.uk). Multiple alignment was performed with CLUSTAL $W$ version 1.6 (Thompson et al. 1994), and the graphic presentation was composed with GeneDoc (Nicholas \& Nicholas 1996).

Northern blot. RNA was extracted from liquidnitrogen pulverized sponge tissue with TRIzol Reagent (GibcoBRL) as recommended by the manufacturer. An amount of $7.5 \mu \mathrm{g}$ of total RNA was electrophoresed through $1 \%$ formaldehyde/agarose gel and blotted onto Hybond $\mathrm{N}^{+}$membrane following the manufacturer's (Amersham) instructions. Hybridization experiments were performed in parallel with 2 probes (GCDNAJ and GCHSP70).

The complete cDNA of GCDNAJ, or the cDNA coding for hsp70, GCHSP70 (accession no. X94985; Koziol et al. 1996) labeled with DIG-11-dUTP by the DIG DNA labeling kit, was used. Hybridization was per- formed with the antisense DIG-labeled probes at $42^{\circ} \mathrm{C}$ overnight using $50 \%$ formamide, containing $5 \times \mathrm{SSC}$ (sodium chloride/sodium citrate buffer), $2 \%$ blocking reagent (Boehringer Mannheim), $7 \%$ (w/v) SDS (sodium dodecyl sulphate) and $0.1 \%(\mathrm{w} / \mathrm{v}) \mathrm{N}$-lauroylsarcosine, following the manufacturer's (Boehringer Mannheim) instructions. After washing, DIG-labeled nucleic acid was detected with anti-DIG Fab fragments (conjugated to alkaline phosphatase) and visualized by the chemiluminescence technique using CDP, the chemiluminescence substrate alkaline phosphatase, according to the manufacturer's (Boehringer Mannheim) instructions.

For quantitation of the signals of Northern blots the chemiluminescence procedure was applied (Stanley \& Kricka 1990); CDP was used as substrate. The screen was scanned with the GS-525 Molecular Imager (BioRad).

\section{RESULTS}

\section{Cloning of GCDNAJ cDNA from Geodia cydonium}

GCDNAJ was cloned using a degenerated PCR primer for amplification in a cDNA library from the marine sponge Geodia cydonium. PCR clones were found to be homologous to DnaJ-like cDNAs (Eucarya) and DnaJ cDNAs (Bacteria and Archaea) as analyzed by searches with BLITZ and FASTA. The resulting cDNA clone is 1476 base pairs (bp) long (submitted to EMBL/GenBank database, accession no. Y09037) and was termed GCDNAJ.

The open reading frame in GCDNAJ is $1236 \mathrm{bp}$ long and predicts a 412 aa long protein with a deduced $M_{r}$ (relative molecular weight) of 45542 and $\mathrm{pI}$ (isoelectric point) of 5.24 (PC/GENE 1995) (Fig. 1).

Northern blot analysis using the original sponge GCDNAJ clone as a probe (see below) revealed 1 band of a size of $1.5 \mathrm{~kb}$, confirming the presence of the complete transcript

\section{Deduced aa sequence of DNAJ_GEOCY}

The deduced aa sequence of GCDNAJ, DNAJ_ GEOCY, comprises the motifs characteristic for most members of the DnaJ family (Bork et al. 1992) (Fig. 1). It consists of the $\mathrm{N}$-terminal conserved region (Georgopoulos et al. 1994, Tsai \& Douglas 1996) including the $J_{N}$ domain spanning aa F44 to Y63, followed by the G/F (Gly/Phe-rich motif; G67 to G104) region, with $14 \mathrm{G}$ and $5 \mathrm{~F}$ aa residues (Wall et al. 1995). In addition to the $\mathrm{N}$-terminal conserved DnaJ domain, the further conserved DnaJ domain signature CxxCxGxG[AGS]xxG 
DNJ2_HUMAN : DRJ1 DROME: DNA J_GEOCY MAS5_YEAST DNJH ARATH DNJH_CUCSR DNJ1_RLLPO DNAJ LACLA DNAJ ECOL I DNA J_METMA DRJ1 DROME DNAJ_GEOCY MAS5 YEAST DNJH_ARATH DNJH_CUCSA : DNJ1_ALLPO DNAJ LACLA DNAJ_ECOLI : DNAJ_METHA :

DNJ2_HUMAN DRJI_DROME DNAJ GEOCY MAS5 YEAST DNJH_ARATH : DNJH CUCSA DNJI ALLPO : ONAJ_LACLA. ONAJ_ECOLI DNAJ METMA :

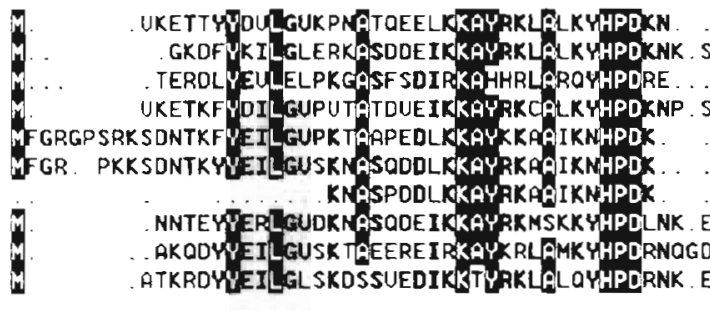

PNEGEK-
SPRAEERY

GGNDEK

SEEAREK GEOPEK GGDPEK GGDPEK

EGAEEK Y

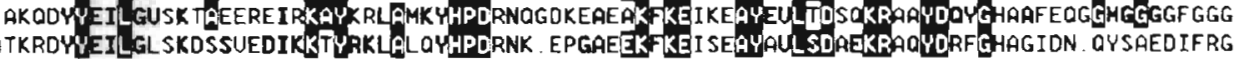

DnaJ signature $[\mathrm{N}-\mathrm{t}]$

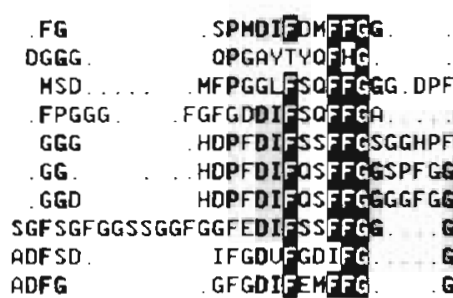

C. . GRMORER RGKNUUHOLSUTLEDLYNGATRKLAL OXNUI GDKCEGRGGGKTRU . ECCPNGRE .DPR . ATFAOFFGSSDPFGAFFTEGDNMFSGGOG . GNTNEIFWNIGGDDMFAFNAQA GMSG . GRPRAPRAE T I I I LEUTLEDUYS EA TKYUEYKRKULCK TCNGGTGERHGTU. URCRNCKK GGAORPRGPQ . RGKDIKHEISASLEE LYKGRTAKLALNKAILEKECETRGGKKGAU KKCTSCNC

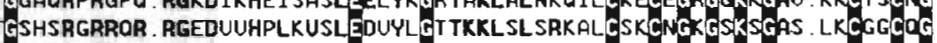
GEGSSRGRROR. RGEDU I HPLKUSLEDL YNGT SKKLLLSRNUICSKCKGG GSKSGPS. MKCPGCOG

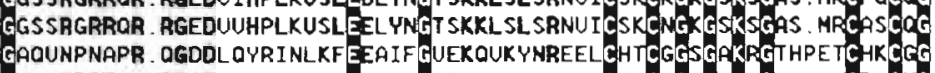

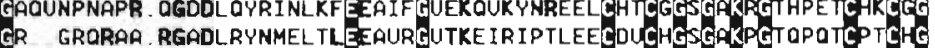
GERRGGPMGPR. RGSDLQYOLYUTFEEARFGURKDIDIPRTERCSTCSSGGARPGTSPKRCPNEGG

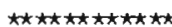

DnaJ signature

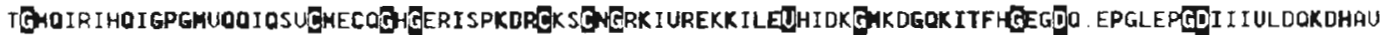
PS. RKRPEDPP IUHOLFUSLEEUD. KGC IKKMK I SRMATGSNGPYKEEKULR I TUKP GUK AGTKIIFPOEGDS APNKTPAOIUF I IROKPHSL TGIQUSHRPL GPGF IQQI OSACGDCGGT GDF RREKDRCKKCKGKRIUEUDEKLEDKUSPGNGHNOK IPFRGKADE. IPDGDAGDUIUILQE. EEPR DGIKFUTROHGP MIORF TECDUCHGTIGDI IDPKDRCKSC +GKKUENERK ILEUHUEPGMKDGORIUFKGEADO APDUI PGDUUF IUSERPHKS

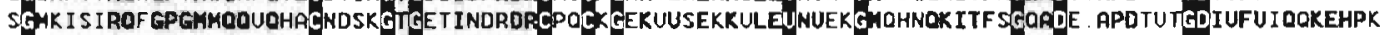

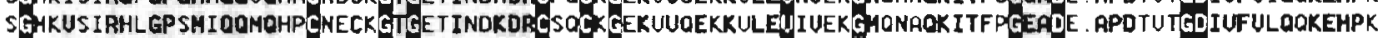
SGHKUS I ROL GPGM IOOMOHPCNDCK GTGEMINDKDR.CPL CKEKUUOEKKULEUHUEKGMONGQR ITF PGEADE APDTUTGDIUFULDOKEHPK RE. OINUURDTPLGRMOTOUTCDUCNGTEKEIKEK. CETCHESGHEKUAHTURUTUPAGUE TGOKMRLQGOGDAGUNGGPYGDL YUUF QUEASDK SG QUOMROG FF UUQOTCPHCOGRGTLIKDP. . CNKCHEHGRUERSKTLSUKIPRGUD TGDRIRLAGEGEAGEHGAPREDL YUQUQUKOHPI TG OURTTRSTL GMOFUSTTTCSACHGRGOUUESP. CPTCSEAGRURSRRKMSUNUPAGADSGMTLRLSGEGDAGEPGAP SEDL Y I IUHUMEHKY

80

DNJ2_HUMAN DRJ1_DROME DNA J_GEOCY : MAS5 YEAST DNJH_ARATH DNJH CUCSA DNJ1_ALLPO : DNAJ_LACLA DNAJECOLI : DNAJ_METMA

REEDLFHCMDIQLUEALCGFHKP ISTL. DNRT IUI TSHPGOIUKHGDIKCULNEGMYPIYRRPYEKERL I IEFKUNFPENGFLS. POKLSLL REG IDLKYTAOISLKOALCGNGSUCPRCR. ARIOUNPNHEI IKPTTTRRINGLGLPUPKEPSRREOLIUSFDIKFPDT. LAP. SLONOL PLPNEFG IESHDG TRL SEALCGCEFCREAI LDGQQLLUKT I PGEUIAPDSUKGIRELGMPSERHTTNKGNLYIKF II OFPDSGFLPSEEEREKL FXADGDOL UYEAETOLLTAI I RGGEFRLEHUS. GDWLKUG IUPGEUIAPGMRKUIEGKGMP I PKYGG. YGNLI IKF TIKFPENHF TS. EENLKKL RKGEDLFUEMT ISL TEQLCGF OFUL THL . DKRQLLIKSKPEEUUKPDSYKAISDEGMPIYOSPFMKEKLYIHFTUEFPES. LSP. . DQTKAI KGDDLFEHTL SLUESLCGFOFILTHL DGROLL IXSLPGEUUKPDOFKATNDEGPHYORPFHKEKLYTHFSUEFPS LNP EOCKAL AKGDDLFYKHTLSLTERLCGF OFUL THL. DGRQLLIKSNPGEUUKPDOFKAINDEGHPHYORPF MREKLYIOF LUDFPOS LTP. DQCKUI RDGAEIYYKMPMDFUCGALGDEIEUPTUH. GNUKLKIPAGTOTGANFRLK. GKGAPKLRGSG. NEDOYUI INIUTPXN. LNO. AQKEAL EGNNLYCEUPINF AMAALGGE IEUPTL.D. GRUKLKUPGETOTGKLFRMR. GKGUKSURGGA. OGOLLCRUUUETPUG . LNE. RQKOLL UDYDUISELPISF TQRALGADIMUDTLY GKUKMNIPSGTOTHSUFRLK. OKGIORLQGHG KGOQLURUIIRTPTK LTO. EQKOLL

Fig. 1 Geodia cydonium. Alignment of the a sequence for DNAJ_GEOCY, deduced from the cDNA GCDNAJ, with selected DnaJ sequences from other organisms. Alignment was performed with the DnaJ from the following: Metazoa/fungi: human (DNJ2_HUMAN, accession no. P31689), Drosophila melanogaster (DRJ1_DROME, U34904), Saccharomyces cerevisiae (MAS5_YEAST, P25491); plants: Arabidopsis thaliana (DNJH_ARATH, P42825), Cucumis sativus (DNJH_CUCSA,Q04960) and Allium porrum (DNJ1_ALLPO, Q03363); prokaryotes: (1) 2 bacteria, Lactococcus lactis (DNAJ_LACLA, P35514) and Escherichia coli (DNAJ_ECOLI, P08622), and (2) 1 archaebacterium, Methanosarcina mazes (DNAJ_METMA, P35515). The sequences have been truncated at the C-terminus because of the known low homology un this region (Georgopoulos et al. 1994). The DnaJ signatures at the $\mathrm{N}$-terminal region [DnaJ signature $(\mathrm{N}-\mathrm{t}$ )] and the further DnaJ domain signature (DnaJ signature) are marked

(Tsai \& Douglas 1996) is found in the C-terminal region from aa C141 to G152, followed by 2 Zn fingers (C157, C160 to C184, C187; C200, C203 to C279, C282).

Evolutionary conservation of DnaJ-like proteins

An alignment of the following DnaJ-like a a sequences is shown in Fig. 1. Metazoa/fungi: Geodia cydonium (DNAJ_GEOCY), human (DNJ2_HUMAN), Drosophila melanogaster (DRJ1_DROME), Saccharomyces cere- visiae (MAS5 YEAST); plants: Arabidopsis thaliana (DNJH_ARATH), Cucumis sativus (DNJH_CUCSA) and Allium porrum (DNJ1_ALLPO); and prokaryotes: 2 bacteria [Lactococcus lactis (DNAJ_LACL) and Escherichia coli (DNAJ_ECOLI)] and 1 archaeon [Methanosarcina mazei (DNAJ_METMA)]. This alignment reveals the high sequence identity between the sponge molecule and the sequences from eukaryotic organisms of $45 \%$ (A. thaliana) to $36 \%$ (human) and prokaryotic organisms of $30 \%(E$ coli) to $28 \%(M$. mazei). 


\section{Increased expression of hsp70 in Geodia cydonium after temperature shock}

Untreated control samples from Geodia cydonium did not show any expression of the hsp 70 gene (Fig. 2 lane a). However, if the cubes were treated at elevated temperature the expression of the characteristic $2.2 \mathrm{~kb}$ band, representing the hsp70 transcripts, was markedly increased. After $1 \mathrm{~h}$ the band became visible, the intensity of the band increased further after $2 \mathrm{~h}$ (lane b) and reached a maximum $6 \mathrm{~h}$ after the temperature shift (lane d); subsequently the expression decreased (lane e).

To quantify the signals of Northern blots the chemiluminescence procedure was applied. The results, summarized in Fig. 3, revealed that untreated animals do not contain visible amounts of hsp70 transcripts. The expression level increased after $2 \mathrm{~h}$ and reached a maximum after $6 \mathrm{~h}$; the level reached was 18 -fold higher than one seen after $2 \mathrm{~h}$ (at this time point the expression was set to 1 -fold).

It must be mentioned that in addition to the $2.2 \mathrm{~kb}$ band, characteristic for hsp70 transcripts, a further clear band of $1.9 \mathrm{~kb}$ is seen (Fig 2). This band is very likely not an artifact, because (1) the signal is absent at time zero (lane a), (2) it increases in strength after a

a $\quad$ b $\quad c \quad d \quad$ e $\quad k b$

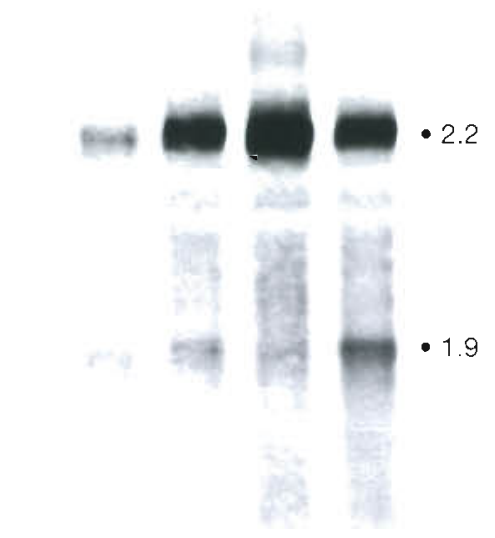

$\begin{array}{llllll}0 & 2 & 4 & 6 & 8 & \text { hs (h) }\end{array}$

Fig. 2. Geodia cydonium. Northern blot analysis for the determination of the expression of the hsp 70 gene. The cubes were incubated for 0 to $8 \mathrm{~h}$ at elevated temperature. RNA was extracted, $7.5 \mu \mathrm{g}$ of total RNA from each sample was electrophoresed through $1 \%$ formaldehyde/agarose gel, blotted and hybridized to the DIG-labeled GCHSP70 probe. The size of the 2 bands, $2.2 \mathrm{~kb}$ (hsp 70 transcripts) and $1.9 \mathrm{~kb}$ (unknown transcript), is marked; time of heat stress (hs) in $h$ is given longer incubation period (lanes b to e) and (3) it has not been seen before during our hybridization studies using the Geodia cydonium model.

\section{Modulation of DnaJ-like gene expression in Geodia cydonium after temperature shock}

The expression of the sponge DnaJ-like gene was also analyzed by Northern blotting. RNA was extracted from the same animal samples which were used for the determination of the expression of hsp 70 gene. At time zero the DnaJ-like gene was already expressed and could be identified using GCDNAJ as a probe (Fig 4A lane a, B lane a); the size of the transcript was $1.5 \mathrm{~kb}$. Temperature stress did not markedly change the extent of expression during the total incubation period of $8 \mathrm{~h}$.

The expression rate was also quantitatively analyzed by the chemiluminescence technique and the data are summarized in Fig. 3. It is obvious that the amount of transcripts increased after a $2 \mathrm{~h}$ incubation from 0.35 to 1 -fold; at time $1 \mathrm{~h}$, the level of DnaJ-like gene expression was reduced to 0.08 (means from 4 parallel experiments). The increased level of DnaJ-like gene expression seen after $2 \mathrm{~h}$ did not markedly change during longer incubation.

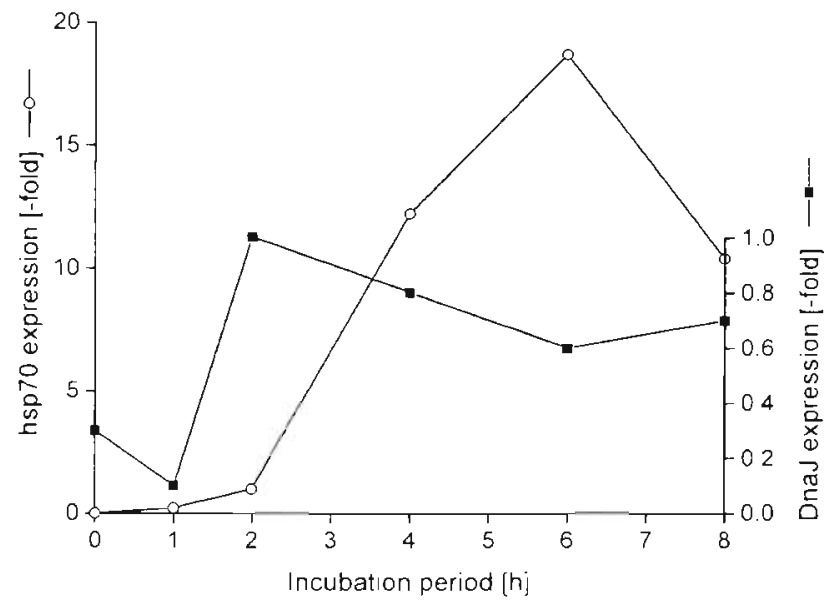

Fig. 3. Geodia cydonum. Quantification of expression of both the hsp70 gene and the gene encoding DnaJ-like protein after transfer of the cubes to elevated temperature. After the indicated period of incubation ( 0 to $8 \mathrm{~h}$ ) the RNA was extracted, size separated and hybridized to the 2 cDNA probes. The intensities of the $2.2 \mathrm{~kb}$ band of the hsp70 gene (Fig. 2) and the $1.5 \mathrm{~kb}$ band (Fig. 3), representing the DnaJ-like transcripts, were analyzed with the GS-525 Molecular lmager The intensities of the bands after a $2 \mathrm{~h}$ incubation period were set arbitrarily 1 -fold. Left ordinate: values for the hsp70 expression $[-0-]_{i}$ right ordinate: expression of the gene encoding the DnaJ-like protein $[\rightarrow-1$; note the different scales. Means of 4 parallel experiments are given; SDs do not exceed $10 \%$ 


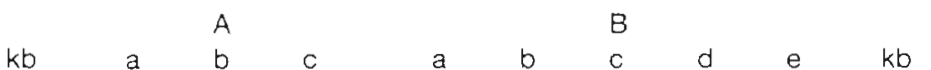

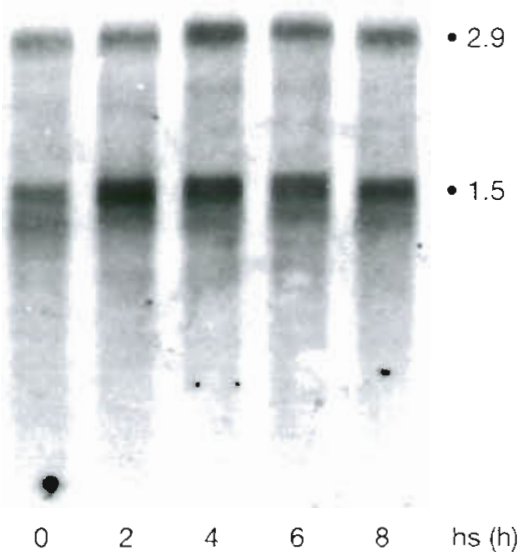

tive and the inducible hsp70 (Yamane et al. 1995) - in the absence of ATP (Sugito et al. 1995). In this complex the ATPase activity of hsp70 is activated and results in the binding of the complex to peptides (Minami et al. 1996) (Fig. 5). While DnaJ in Bacteria is a chaperone by itself (Langer et al. 1992), its role is not yet established in Eucarya. In addition, it became evident that further factors are probably required during hsp70-mediated protein renaturation (Minami et al. 1996).

In order to clarify if, besides an increased expression of hsp70, the expression of the gene coding for a DnaJ-like protein in Geodia cydonium is changed in response to environmental stress, the respective GCDNAJ gene was cloned. GCDNAJ comprises the characteristic DnaJ motifs, known from other Eucarya molecules of this group (Bork et al. 1992), e.g. $J_{N}$ domain, $G / F$ region and $2 \mathrm{Zn}$ fingers. Alignment studies revealed high sequence identity to both DnaJ-like proteins from Eucarya and DnaJ proteins from Bacteria, supporting the evolutionary high conservation of the DnaJ-like proteins (Koziol et al. unpubl.).

The expression of hsp 70 gene and DnaJ-like gene was studied. Experiments performed in parallel revealed that the hsp70 gene is highly expressed after an initial phase of $2 \mathrm{~h}$. This elevation of the transcript level for hsp70 was

As with the Northern blot studies of hsp70, the analyses of DnaJ-like gene expression revealed a second hybridizing band. These 2 bands mapped at $1.9 \mathrm{~kb}$ and $2.9 \mathrm{~kb}$, respectively, for the hsp70 and DnaJ-like transcript. The significance of these bands is described below.

\section{DISCUSSION}

Previously, it was reported that the sponge Geodia cydonium responds to elevated temperature and other physical $(\mathrm{pH})$ (Koziol et al. 1996) and chemical stressors (tributyltin) (Batel et al. 1993) with an increased expression of hsp70. Therefore, the corresponding gene was cloned from a cDNA library from $G$. cydonium (Koziol et al. 1996). With this CDNA, GCHSP70, it was shown that this probe recognizes the transcripts of the inducible hsp70 gene (Koziol et al. 1996)

Recent findings indicate that a DnaJ-like protein in metazoan organisms associates with hsp 70 chaperones - both the constitu- expected considering earlier expression studies (Koziol et al. 1996). However it was surprising that the expression of the DnaJ-like protein was initially reduced, after an incubation period of $1 \mathrm{~h}$, in response to elevated temperature. We have no explanation for this initial drop. Two hours after setting the temperature stress a 3-fold elevation was seen. An initial reduction of the transcript levels for hsp 70 and related stress proteins has been described earlier (Blake et al. 1990) without an explanation. Also at the center of our pre-

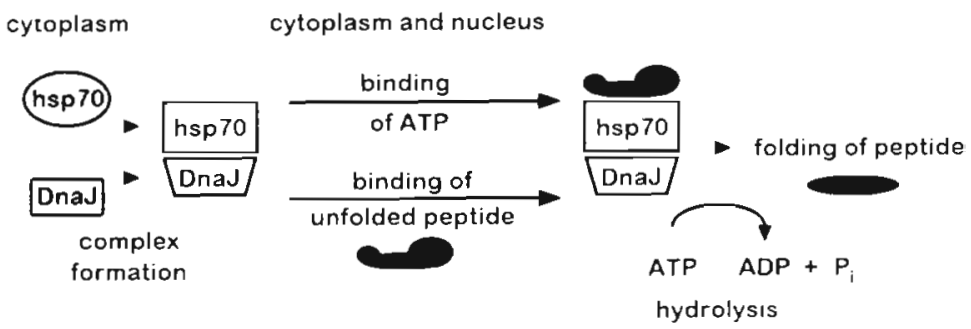

Fig. 5. A model for the role of DnaJ-like proteins during the chaperonefunction of hsp70. After formation of a complex by these 2 molecules hsp70 strongly increases its binding activity to ATP and its affinity to unfolded peptide. If the ternary complex is formed hsp70 causes folding of peptide under consumption of ATP. Modified after Minami et al. (1996) and Yamane et al. (1995) 
sent studies is the clarification of the additional signals seen in the Northern blots, used for detecting the transcripts of the hsp 70 gene, the $1.9 \mathrm{~kb}$ species, and of the DnaJ-like gene, the $2.9 \mathrm{~kb}$ transcript. Analyzing a cDNA clone containing an $1.9 \mathrm{~kb}$ insert which crosshybridized with the GCHSP70 probe revealed that it represents no fragment of the $2.2 \mathrm{~kb}$ transcript of the hsp70 gene. We hypothesize that the $1.9 \mathrm{~kb}$ species seen with the GCHSP70 probe encodes a hsp related to hsp70 of approximately $65 \mathrm{kDa}$, while the $2.9 \mathrm{~kb}$ transcript detected with the GCDNAJ probe might represent a tandem duplication of the DnaJ-like gene (1.5 kb). A tandem duplication of the hsp 70 gene has previously been observed in Trypanosoma cruzi (Requena et al. 1988).

The observed increase of the expression of the DnaJlike gene indicates that sponges have an efficient defense mechanism against temperature changes; first by increasing the level of the gene coding for the chaperone hsp70, and secondly by augmenting the level of the 'associate' factor, the DnaJ-like protein, which is known to be required for the optimal function of the hsp 70 chaperone system.

Acknowledgements. This work was supported by grants from the Bundesministerıum fur Bildung und Forschung (project 'Stresstox'), from the Ministerium für Bildung und Wissenschaft von Rheinland-Pfalz (Biotech-Invest) and the International Human Frontier Science Program (RG-333/96-M)

\section{LITERATURE CITED}

Bachinski N, Koziol C, Batel R, Labura Z, Schröder HC, Müller WEG (1997) Immediate early response of the marine sponge Suberites domuncula to heat stress: reduction of trehalose concentration and glutathione S-transferase activity. J Exp Mar Biol Ecol 210:129-141

Batel R, Bihari N, Rinkevich B, Dapper J, Schäcke H, Schröder HC, Müller WEG (1993) Modulation of organotin-induced apoptosis by the water pollutant methyl mercury in a human lymphoblastoid tumor cell line and a marine sponge. Mar Ecol Prog Ser 93:245-251

Blake M, Gershon D, Fargnoli J, Holbrook N (1990) Discordant expression of heat shock protein mRNAs in tissues of heat-stressed rats. J Biol Chem 265:15275-15279

Boguski MS, McCormick F (1993) Proteins regulating Ras and its relatives. Nature 366:643-654

Bollinger L, Deloche O, Glick BS, Georgopoulos C, Jeno P, Kronidou N, Horst M, Morishima N, Schatz G (1994) A mitochondrial homolog of bacterial GrpE interacts with mitochondrial hsp70 and is essentıal for viability. EMBO J 13:1998-2006

Bork P, Sander C. Valencia A, Bukau B (1992) A module of the DndJ heat shock proteins in malaria parastes. Trends Biochem Sci 17:129

Buchman TG, Abello PA, Smith EH, Bulkley GB (1993) Induction of heat shock response leads to apoptosis in endothelial cells previously exposed to endotoxin. Am J Physiol 265: H165-H170

Cheetham ME, Jackson AP. Anderton BH (1994) Regulation of the 70-kDa heat-shock-protein ATPase activity and substrate binding by human DnaJ-like proteins, HSJ1a and HSJ1b. Europ J Biochem 226:99-107

Fossi MC (1994) Nondestructive biomarkers in ecotoxicology. Environ Health Perspect 102(Suppl 12):49-54

Georgopoulos C, Liberek K. Zylicz M, Ang D (1994) Properties of the heat shock proteins of Escherichia coli and the autoregulation of the heat shock response. In: Morimoto RI, Tissères A, Georgopoulos C (eds) The biology of heat shock proteins and molecular chaperones. Cold Spring Harbor Laboratory Press, Cold Spring Harbor, p 209-249

Gething MJ, Sambrook J (1992) Protein folding in the cell. Nature 355:33-45

Haas IG, Meo T (1988) cDNA cloning of the immunoglobulin heavy-chain binding protein. Proc Natl Acad Scl USA 85: $2250-2254$

Koziol C, Wagner-Hülsmann C, Cetkovic H, Gamulın V, Kruse M, Pancer Z, Schäcke H, Müller WEG (1996) Cloning of the heat-inducible blomarker, the cDNA encoding the $70-\mathrm{kDa}$ heat shock protem, from the marine sponge Geodia cydonium: response to natural stressors. Mar Ecol Prog Ser 136:153-161

Langer T, Lu C, Echols H, Flanagan J, Hayer MK, Hartl FU (1992) Successive action of DnaK, DnaJ and GroEL along with the pathway of chaperone-mediated proteln folding. Nature 356:683-689

Liberek K, Marszalek J, Ang D, Georgopoulos C, Zylicz M (1991) Escherichia coll DnaJ and GrpE heat shock proteins jointly stimulate ATPase activity of DnaK. Proc Natl Acad Scl USA 88:2874-2878

Macario AJ, Dugan CB, Clarens M, Conway de Macario E (1993) DnaJ in Archaea. Nucleic Acids Res 21:2773

Minami Y, Hohfeld J, Ohtsuka K, Hartl FU (1996) Regulation of the heat-shock protein 70 reaction cycle by the mammalian DnaJ homolog, Hsp70. J Biol Chem 271 $19617-19624$

Morimoto RI, Tissères A, Georgopoulos C (eds) (1994) The biology of heat shock proteins and molecular chaperones. Cold Spring Harbor Laboratory Press, Cold Sprnng Harbor

Müller WEG (ed) (1994) Use of aquatic invertebrates as tools for monitoring of environmental hazards. Gustav Fischer Verlag, Stuttgart

Müller WEG (1995) Molecular phylogeny of metazoa (animals): monophyletic orıgin. Naturwissenschaften 82:321-329

Müller WEG, Müller l (1997) Sponge cells and tissue in vitro: useful biomarkers of aquatic pollution. In: Wells PG, Lee $\mathrm{K}$, Blaise $\mathrm{C}$ (eds) Microscale aquatic toxicologyadvances, techniques and practice. CRC Lewis Publishers, Boca Raton, FL (in press)

Müller WEG, Kozıol C, Kurelec B, Dapper J, Batel R, Rinkevich B (1995) Combinatory effects of temperature stress and nomionic organic pollutants on stress proteln (hsp70) gene expression in the fresh water sponge Ephydatia fluviatilis. Arch Environ Contam Toxicol 14:1203-1208

Munro S, Pelham HRB (1986) An hsp70-like protein in the ER: identity with the $78 \mathrm{kd}$ glucose-regulated protein and immunoglobulin heavy chain binding protein. Cell 46 : $291-300$

Nicholas KB, Nicholas HB Jr (1996) GeneDoc: a tool for editing and annotating multiple sequence alignments. Version 1.1.004. Distributed by the author

NRC (National Research Council) (1989) Biologic markers in reproductive toxicology. National Academy Press, Washington, DC, p 395-423

Ohtsuka K (1993) Cloning of cDNA for heat-shock protein hsp40, a human homologue of bacterial DnaJ Biochem Biophys Res Commun 197:235-240 
Ohtsuka K, Masuda A, Nakai A, Nagata K (1990) A novel $40-\mathrm{kDa}$ protein induced by heat shock and other stresses in mammalian and avian cells. Biochern Biophys Res Commun 166:642-647

PC/GENE (1995) Data Banks CD-ROMi Release 14.0. IntelliGenetics, Inc, Mountain View, CA

Pfeifer $K$, Haasemann M, Ugarkovic D, Bretting H, Fahrenholz F, Müller WEG (1993) S-type lectins occur also in invertebrates: unusual subunit composition and high conservation of the carbohydrate recognition domain in the lectin genes from the marine sponge Geodia cydonium. G]ycobiology 3:179-184

Preisig-Müller R, Kindl H (1993) Plant DnaJ homologue: molecular cloning, bacterial expression, and expression analysis in tissues of cucumber seedlings. Arch Biochem Biophys 305:30-37

Requena JM, Lopez MC, Jimenez-Ruiz A, de la Torre JC, Alonso C (1988) A head-to-tail tandem organization of hsp70 gene in Trypanosoma cruzi. Nucleic Acids Res 16:1393-1406

Sarà M. Vacelet J (1973) Ecologie des démosponges. In: Grassé PP (ed) Traité de zoologie: spongiaires. Tome III(1). Masson, Paris, p 462-576

Scheffer U. Koziol C, Pancer Z, Krasko A, Müller WEG (1997) Sponges as biomarkers of the aquatic environment: application of molecular probes. In: Proceedings of the International Conference on Sponge Science. Springer-Verlag. Tokyo (in press)

Schlesinger MJ, Ashburner M, Tissieres A (1982) Heat shock From bacteria to man. Cold Spring Harbor Laboratory Press, Cold Spring Harbor

Stanley PE, Kricka LJ (1990) Bioluminescence and chemilu-

This article was submitted to the editor minescence: current status. John Wiley \& Sons, New York Subjeck JR, Shyy TT (1986) Stress proteln systems of mammalian cells. Am J Physiol 17:C1-C17

Sugito K, Yamane M, Hattori H, Hayash. Y, Tohnaı I, Ueda M Tsuchida $N$, Ohtsuka $K$ (1995) Interaction between hsp 70 and hsp40, eukaryotic homologoues of DnaK and DnaJ, in human cells expressing mutant-type p53. FEBS Lett 358 : $161-164$

Thompson JD, Higgins DG, Gibson TJ (1994) CLUSTAL W: improving the sensitivity of progressive multiple sequence alignment through sequence weighting, positions-specific gap penalties and weight matrix choice. Nucleic Acids Res 22:4673-4680

Tsai J, Douglas MG (1996) A conserved HPD sequence of the $\mathrm{J}$-domain is necessary for YDJ1 stimulation of hsp70 ATPase activity at a site distinct from substrate binding. J Biol Chem 272:9347-9354

van Asseldonk M, Simons A, Visser $H$, de Vos WM, Simons G (1993) Cloning, nucleotide sequence, and regulatory analysis of the Lactococcus lactis dnaJ gene. J Bacteriol 175: $1637-1644$

Vogel S (1977) Current-induced flow through living sponges in nature. Proc Natl Acad Sci USA 74:2069-2071

Wall D. Zylicz M, Georgopoulos C (1995) The conserved G/F motif of the DnaJ chaperone is necessary for the activation of the substrate binding properties of the DnaK chaperone. J Biol Chem 270:2139-2144

Yamane M, Hattori H, Sugito K, Hayashi Y. Tohndi I, Ueda M, Nishizawa K, Ohtsuka K (1995) Cotranslocation and colocalization of hsp40 (DnaJ) with hsp 70 (DnaK) in mammalian cells. Cell Struct Funct 20:157-166

Manuscript received: January 30, 1997

Revised version accepted: May 13, 1997 